IZA DP No. 4404

Services Outsourcing and Innovation: An Empirical Investigation

Holger Görg

Aoife Hanley

September 2009 


\title{
Services Outsourcing and Innovation: An Empirical Investigation
}

\author{
Holger Görg \\ University of Kiel, \\ Kiel Institute for the World Economy \\ and IZA \\ Aoife Hanley \\ Kiel Institute for the World Economy \\ and University of Kiel
}

\section{Discussion Paper No. 4404 \\ September 2009}

\author{
IZA \\ P.O. Box 7240 \\ 53072 Bonn \\ Germany \\ Phone: +49-228-3894-0 \\ Fax: +49-228-3894-180 \\ E-mail: iza@iza.org
}

\begin{abstract}
Any opinions expressed here are those of the author(s) and not those of IZA. Research published in this series may include views on policy, but the institute itself takes no institutional policy positions.

The Institute for the Study of Labor (IZA) in Bonn is a local and virtual international research center and a place of communication between science, politics and business. IZA is an independent nonprofit organization supported by Deutsche Post Foundation. The center is associated with the University of Bonn and offers a stimulating research environment through its international network, workshops and conferences, data service, project support, research visits and doctoral program. IZA engages in (i) original and internationally competitive research in all fields of labor economics, (ii) development of policy concepts, and (iii) dissemination of research results and concepts to the interested public.
\end{abstract}

IZA Discussion Papers often represent preliminary work and are circulated to encourage discussion. Citation of such a paper should account for its provisional character. A revised version may be available directly from the author. 
IZA Discussion Paper No. 4404

September 2009

\section{ABSTRACT}

\section{Services Outsourcing and Innovation: An Empirical Investigation*}

We provide a comprehensive empirical analysis of the links between international services outsourcing, domestic outsourcing, profits and innovation using plant level data. We find a positive effect of international outsourcing of services on innovative activity at the plant level. Such a positive effect can also be observed for domestic outsourcing of services, but the magnitude is smaller. This makes intuitive sense, as international outsourcing allows more scope for exploiting international factor price differentials, therefore giving the establishment higher profits and more scope to restructure production activities towards innovation. We also find that international services outsourcing has a positive effect on profitability, as predicted by theory, while this is not true for domestic sourcing. The results are robust to various specifications and an instrumental variables analysis.

JEL Classification: F19, O31

Keywords: $\quad$ services outsourcing, offshoring, innovation, R\&D

Corresponding author:

Holger Görg

Kiel Institute for the World Economy

Düsternbrooker Weg 120

24105 Kiel

Germany

E-mail: holger.goerg@ifw-kiel.de

\footnotetext{
* We are very grateful to Forfás for the provision of the data and to Sourafel Girma, Catia Montagna, Frances Ruane, Vincenzo Quadrini, seminar participants at Aarhus School of Business, Queen Mary University of London, University of Göttingen, University of Munich, ESRI Dublin, CEPII Paris, IfW Kiel, and anonymous referees for helpful comments. Also, financial support from Nottingham University through Grant No. NLF A2 RBL6 and the Tuborg Foundation is gratefully acknowledged.
} 


\section{Introduction}

The practice of sourcing services inputs from abroad has increased substantially over the last decades. For example, Amiti and Wei (2006) document that in the US international outsourcing of services by manufacturing firms has grown at an annual rate of around 6 per cent over the period 1992 to 2000. If anything, this growth is likely to have accelerated in more recent years. This trend has given rise to public debates and policy concerns about the possible impact of this increasingly global division of labour. ${ }^{1}$ Trade economists have also got involved in this debate, generally using a response based on intuition derived from simple trade theory: international outsourcing of production allows firms to access cheaper inputs abroad, foster gains from international specialisation and will hence lead to the restructuring of production in the industrialised countries towards more “skill intensive” or "innovative” activities. ${ }^{2,3}$

In a standard Heckscher-Ohlin model this is an argument made at the level of the economy: there will be restructuring out of low skill intensive sectors and into high skill intensive sectors in the skill abundant industrialised country. This will imply adjustment costs for workers laid off in the outsourced sectors who may or may not be able to move into employment in the other sector (e.g., Davidson and Matusz, 2000). A related yet slightly different question is what will happen in the firm that does the outsourcing? Here,

\footnotetext{
${ }^{1}$ Preceding the rise of services outsourcing, the outsourcing of materials attracted considerable attention. A sizeable amount of research has been devoted to attempting to understand the causes and consequences of this type of disintegration of production. For example, Swenson (2000, 2004) and Görg (2000) examine empirically the determinants of international outsourcing of materials. Feenstra and Hanson (1999), Head and Ries (2002) and Geishecker and Görg (2008) consider the implications for domestic labour markets.

${ }^{2}$ See, for example, Blinder (2006) for a good discussion. Blinder not only points out the "textbook" gains but also argues that the current wave of offshoring brings with it additional challenges, as basically speaking all manufacturing and services activities that do not require face-to-face contact are potentially outsourcable from the industrialised countries. Eaton and Kortum (2006) provide a recent theoretical model dealing with the relationship between trade and innovation.

${ }^{3}$ A recent study by Deutsche Bank Research (2004) illustrates the scope for factor costs savings through international outsourcing of services. They calculate that the hourly rates for computer programmers in Germany were $€ 54$ in 2004 comparable with rates of $€ 44$ in the US. In industrialising countries the same labour could be provided for €9.24 in Russia, €14 in Portugal and China €7 in India. Of course, these statistics hide any underlying productivity differences but they do nonetheless highlight wage differences and provide strong reasons for the outsourcing of international services.
} 
models with homogeneous firms (such as Glass and Saggi, 2001) or heterogeneous firms (e.g., Antras and Helpman, 2004) illustrate a similar process. Firms outsource part of the production and concentrate home production on what may be termed their "core activity".

Recently, a small but growing literature using firm or plant level data has established empirically that international outsourcing, in particular of services inputs, is associated with higher productivity in the outsourcing plant, in line with such theory (e.g., Hijzen et al., 2009, Görg et al., 2008 and Tomiura, 2007). However, these papers are largely silent on the mechanisms as to how international outsourcing may affect productivity at the level of the firm or plant. Our goal is to contribute to this literature by examining directly how international outsourcing of services activities impacts on innovative activity in the outsourcing establishment. We ask the specific question of whether a firm that sources some of its service activities abroad, consequently increases its rate of innovation - which is what the theoretical argument would suggest. As far as we are aware, this paper is the first to address explicitly the link between international outsourcing and innovative activity empirically. ${ }^{4}$

We expand on this seemingly straightforward relationship by addressing a number of related questions. A theoretical model by Glass and Saggi (2001) predicts that firms outsource activities due to lower factor costs abroad. Hence, outsourcing leads to higher profits, which are then reinvested in higher $R \& D$ expenditure. We check explicitly whether we can observe this "outsoucing - profit” channel, and its relationship with innovation, in our data. Secondly, we also consider domestic outsourcing and contrast the effects domestic and international outsourcing have on profits and innovation. In that respect, we provide some evidence that relates to a recent paper by Leahy and Montagna (2008) which

\footnotetext{
${ }^{4}$ Tomiura (2009) investigates whether there is a difference in the propensity to outsource depending on a firm's technology intensity, measured in terms of R\&D intensities, but does not look at how outsourcing affects firms' innovation activity. A related literature has looked at correlation between firms' export activity, foreign ownership and innovation, see, e.g., Criscuolo et al. (2005) for a recent paper for the UK.
} 
shows that domestic outsourcing may lead to reductions in operating profits by the outsourcing firms, due to a strategic motive for outsourcing. We discuss these theoretical ideas in Section 2.

To investigate the link between outsourcing of services, profits and innovation at the level of the establishment empirically, we use plant level data for the Republic of Ireland. This is an economy where international services outsourcing appears to be much more important than in the US. In our data, the average ratio of internationally outsourced services to sales is around 4 percent over the period 2002 to 2004. Although not perfectly comparable, these mean values appear higher than those found by Amiti and Wei (2006) for the US. They report that between 1992 and 2000, services outsourcing (calculated similarly as imported services over total production in a sector) increased from 0.2 to 0.3 percent. $^{5}$ Our data run up to the year 2004, and hence capture much of the very recent activity in international outsourcing.

The data set provides a unique source to study these links. Unlike many data sets that have been used in the past, it does not only provide us with plant level information on international outsourcing of services and R\&D expenditure (as a proxy for innovation), but also contains information on domestic outsourcing. Hence, we are able to compare and contrast the effects of international and domestic outsourcing on innovation. This is important as, a priori, it is not clear that the two modes of outsourcing should have the same effects on innovation or profits. Furthermore, the data also allow us to pay particular attention to the possible endogeneity of the outsourcing decision using instrumental variables techniques. We have available a number of establishment level variables that we

\footnotetext{
${ }^{5}$ When we apply the median values, we get a picture more consistent with the US data although still higher. The median ratio of internationally outsourced service inputs to sales is around 0.8 percent in our data. From our data we can also calculate the measure of international services outsourcing for the full sample in 2000. This shows that the mean of this ratio stands at roughly 3 percent (with the median at 0.6 percent). Hence, it is unlikely that the higher values of international services outsourcing are merely due to our sample covering more recent years.
} 
consider to be good instrumental variables candidates for outsourcing activities of plants. These are discussed in detail in the empirical analysis below.

Previewing our results briefly, we find that there are indeed positive effects of international services outsourcing on innovation, in line with expectations. These effects appear stronger than those of domestic outsourcing of services. Furthermore, we establish that international outsourcing of services has a positive effect on profitability in the plant, while this is not true for domestic outsourcing. ${ }^{6}$ These results are robust to various specifications which among other things also control for outsourcing of materials, and also hold in an instrumental variables approach.

The remainder of the paper is structured as follows. Section 2 discusses the expected link between outsourcing, innovation and profits. Section 3 describes the methodology used in the empirical analysis. This is followed by an overview of the data and some summary statistics in Section 4. Section 5 presents the results of our analysis and Section 6 concludes.

\section{Outsourcing, innovation, and profits}

We use the theoretical analysis by Glass and Saggi (2001) as a starting point for our empirical analysis. They develop a model, based on Ricardian technology differences between an industrialized Northern and a less advanced Southern country, to explain the effect of outsourcing on wages and innovation in the North. In their model, potential wage savings will prompt the North to outsource those processes from the South which are relatively low in technological complexity and retain those other processes which are more truly original, innovative or relatively near the technological frontier. The predicted result is that the wage rate (relative to the South) in the North falls due to outsourcing.

\footnotetext{
${ }^{6}$ The latter finding may reflect firms' choosing to outsource domestically due to strategic reasons as in Leahy and Montagna (2008).
} 
While this result is not new, the innovation in Glass and Saggi (2001) is to set this into a dynamic setting, which shows additional positive effects of outsourcing. As cost savings are realised (due to the reduction in the wage in the North) firms' profits rise. These additional profits get reinvested (fully or partially) in Northern innovation through increasing $R \& D$ expenditure. Hence, the profits accruing to the firm from wage savings can be ploughed back into $R \& D$ in order to shift the technological frontier in the North further outward. As such the predicted effect of international outsourcing on innovation is unequivocal in the model: increased proportions of international outsourcing lead to higher innovation rates in the outsourcing establishment. ${ }^{7}$ Hence, we would expect to be able to identify two effects of international services outsourcing in our data. First, it should lead to increased profits and, second, it should raise innovative activity in the outsourcer. Note that the latter effect, strictly speaking, works through the profit channel; outsourcing raises profits and, as a result, increases innovation.

However, outsourcing may, over and above the "profit channel” have a more direct effect on innovation. Outsourcing allows a plant to restructure activities towards more skill intensive (innovative) activity. This may happen immediately, which only as a result of the innovation leads to increases in profitability. While this would be observationally similar to the "outsourcing-affecting-profits" hypothesis it would be different in the chain of events, as outsourcing first affects innovation which in turn impacts on profits. Hence, in the empirical analysis this would imply that we may find an effect of outsourcing on innovation even when controlling for contemporaneous profits. Unfortunately, however, we cannot investigate this hypothesis fully empirically, due to the short time dimension of our data. There are, of course, also other data related issues for why we may find both

\footnotetext{
${ }^{7}$ We should qualify this by saying that positive benefits from international outsourcing are expected to tail off after a certain point. As ever more activities closer to the technical frontier are outsourced abroad, so too does the ease at which foreign manufacturers pose a competitive threat to the North.
} 
outsourcing and profits affecting innovation in an empirical model. These are discussed below in the empirical part.

The Glass and Saggi (2001) model only covers international outsourcing and does not consider domestic outsourcing. In the empirical analysis we distinguish these two types. International outsourcing is likely to be strongly driven by international factor cost differences, as in the theoretical model. Domestic outsourcing may of course also be driven by some factor cost differences between regions but these are unlikely to be as important as the potentially much larger international factor cost differences are for international outsourcing. Domestic outsourcing is more likely to reflect mainly efforts by the firm to respond to competitive pressure through restructuring activities and gains from specialising in core activities.

In this regard, Leahy and Montagna (2008) develop a model of final good producing firms' choice to outsource domestically. Their setup is a two firm oligopoly where firms compete in Cournot competition. Outsourcing implies that the supplier undertakes some relationship specific investments (which determines the quality of the intermediate) after it has been chosen as supplier. Due to the impossibility of agreeing on the level of this investment ex ante, there is the possibility that the supplier provides lower quality inputs, which may lead to the production costs of the final good producer increasing relative to a scenario where it chooses no outsourcing. However, outsourcing may still be preferred by the firm because of its strategic motive. Given that the competitor knows that the firm will face higher production costs if it outsources, the rival will also invest less in quality - it is less aggressive. Hence, through outsourcing, the firm induces in the competitor an incentive to invest less in quality, which in turn affects positive its total output. Hence, Leahy and Montagna (2008) show that firms’ outsourcing decision may lead to higher costs, and lower profits as a result. While their model focuses on domestic outsourcing, it 
is of course also plausible that this strategic motive matters for international outsourcing. However, the cost reduction motive, which unambiguously always leads to higher profits associated with outsourcing, is likely to be stronger for international outsourcing than domestic outsourcing.

The analysis in our paper provides empirical evidence related to these theoretical hypotheses. We study in detail the relationship between innovation (measured as $R \& D$ activity) and outsourcing. While we start with international outsourcing we also consider domestic outsourcing, and compare the effects both types have on innovation. Furthermore, we explicitly consider the relationship between profits and innovation. In particular, we check whether the effect of outsourcing on innovation can be fully explained by the profit variable or whether, for some reason, outsourcing has an effect on innovation even when controlling for contemporaneous profits. Moreover, we investigate what the relationship is between outsourcing and profits - does outsourcing increase profits (as in Glass and Saggi, 2001) or is there evidence in line with the strategic motive of outsourcing highlighted by Leahy and Montagna (2008) which may lead to outsourcing implying a reduction in operating profits?

\section{Methodology}

We start the empirical investigation by examining the hypothesis that international outsourcing of services can impact on plants' innovation activity. To do so we formulate the following empirical model,

$$
\begin{aligned}
& (R \& D / Y)_{i t}=\beta_{1} \text { int_outs } \text { it }-1_{2}+\beta_{2} \text { dom }_{-} \text {outs }_{i t-1}+\beta_{3} \text { profitratio }_{i t-1}+ \\
& \beta_{4} X_{i t-1}+d_{t}+d_{j}+\mu_{i}+\varepsilon_{i t}
\end{aligned}
$$


where the measure of innovation activity employed is the $R \& D$ intensity, defined as $R \& D$ expenditure over total sales, for plant $i$ at time $t$. On the right hand side, int_outs is a measure of international outsourcing of services (defined as imported services inputs relative to sales) at the level of the plant. ${ }^{8}$

The vector $X$ considers a number of other plant characteristics that have been identified in the literature as affecting R\&D activity. We include logged employment as a proxy of firm size, as well as dummy variables indicating whether a firm invests in inhouse training or is an exporter. The latter controls for the possibility that export active firms may also be more $R \& D$ and innovation intensive (e.g., Criscuolo et al., 2005; Salomon and Shaver, 2005). Training activity is included as a rough measure of investment in skills (e.g., van Dijk et al., 1997). From theory, the expected relationship between this variable and $R \& D$ intensity is ambiguous, as investment in skills and $R \& D$ can be either complements or substitutes (e.g., Redding, 1996). Finally, Acs and Audretsch (1991) and Kohn and Scott (1982), among others, show that plant size is an important determinant of R\&D and innovation activity. Hence, we control for this variable in the estimation. ${ }^{9}$

In order to properly identify the effect of international services outsourcing on R\&D, we also consider two further variables. As the theoretical model by Glass and Saggi (2001) shows, international outsourcing has an effect on innovation because it increases profits, which can then be reinvested in R\&D. Hence, we control for profitability in order to examine whether it captures all of the (potential) effect of outsourcing on innovation. It is likely that international services outsourcing has an effect on $R \& D$ even when we control for profitability, for a number of reasons. From an empirical point of view, outsourcing

\footnotetext{
${ }^{8}$ This measure is, thus, somewhat in line with the definitions used by Feenstra and Hanson (1999) and Amiti and Wei (2006) for aggregate data.

${ }^{9}$ Note that it would also be important to control for nationality of ownership, given that foreign-owned firms in Ireland are generally found to be less R\&D active than domestic firms (e.g., Cassidy et al., 2005). The nationality of ownership information in our data is time invariant, however, which implies that this is captured by the plant specific effect included in the model.
} 
may not impact immediately on profits but this may take some time. Including first lags of both services outsourcing and profitability in the model would therefore not capture these more long-term effects. Secondly, it is difficult to measure economic profitability accurately and our variable may not be a perfect proxy for profits. Thirdly, outsourcing may have a more direct effect on innovation. It may allow the plant to immediately restructure activities towards innovation, which only as a result of the innovation leads to increases in profitability.

As an additional variable we also include domestic outsourcing of services in our model. The main aim here is to see whether domestic and international outsourcing have similar effects on innovation. A priori it is not clear that they should, as international outsourcing is more likely to be strongly driven by factor cost differences, while domestic outsourcing may reflect strategic and other motives. In additional robustness checks we also control for the levels of international and domestic outsourcing of materials. While this is not the main focus of our paper, it may be important to control for these as services and material outsourcing may be correlated and, hence, not controlling for this would lead to biased estimates of the effects of services outsourcing.

Finally, the equation also includes a full set of three digit industry dummies and a full set of time dummies to control for any sector specific time varying effects that are unobserved in this econometric specification. The final error term is composed of a plant specific time invariant effect $\mu_{i}$ and a remaining white noise error term $\varepsilon$. Note that in the econometric specification, all plant level control variables are included as one year lags in order to minimise potential endogeneity problems, but also to allow for time lags in the effect. $^{10}$ For example, services outsourcing in time $t$ may only affect R\&D activity in later

\footnotetext{
${ }^{10}$ We also deal with endogeneity more appropriately using an instrumental variables approach, see details below.
} 
periods. While it would be ideal to allow for longer lags this is not possible given the short time dimension in our panel.

Glass and Saggi (2001) show that international outsourcing allows firms to increase profits (due to international factor cost differences) which in turn allows them to spend more on $R \& D$. In order to investigate explicitly the relationship between services outsourcing and profits we also estimate a second equation

$$
\text { profitratio }_{i t}=\gamma_{1} \text { int_outs }{ }_{i t-1}+\gamma_{2} \text { dom_outs }_{i t-1}+\gamma_{3} Z_{i t-1}+d_{t}+d_{j}+v_{i}+\phi_{i t}
$$

where $Z$ is a vector of plant and industry characteristics including log employment as a measure of size, a plant's market share (in terms of sales) in the three digit industry and two (potentially time varying) dummies for plants that are exporters or provide in-house training. The latter two variables capture the fact that exporters and skill intensive firms can be expected to be more productive and profitable. At the industry level, we include the growth rate of three digit industry sales. This variable, together with the market share variable, proxy levels of competition in the industry and the plant's relative standing in it. This is an important determinant of profitability (Shepherd, 1972). Also, in addition to international outsourcing we again include domestic services outsourcing in the equation. If the factor cost saving motivation for international outsourcing is dominant, we would expect the coefficient $\gamma_{1}$ to be positive in the estimation. The coefficient on $\gamma_{2}$ may be positive or negative, depending on how important the strategic motive, which may lead to reductions in operating profits, is for domestic outsourcing.

In the first instance we estimate the two equations separately using a fixed effects panel estimator treating lagged outsourcing (international and domestic) as exogenous. We relax this assumption subsequently using instrumental variables for the outsourcing 
variables in both equations (which are within transformed to purge the plant specific fixed effect). The details of this are discussed in Section 4. Furthermore, it may be the case that profits are endogenous in equation (1), and moreover that the two error terms $\varepsilon$ and $\phi$ are correlated. In order to allow for these possibilities we also estimate within-transformed versions of the two equations jointly using a three stage least square estimator also treating lagged international and domestic outsourcing as endogenous.

\section{Data description and preliminary analysis}

For the econometric part of our paper, we use recent micro-data from the Republic of Ireland. This is plant level information collected by Forfás, the Irish policy and advisory board with responsibility for enterprise, trade, science, and technology in Ireland. Specifically, our data source is the Annual Business Survey of Economic Impact (ABSEI), covering the period from 2000 until 2004. This is an annual survey of plants in Irish manufacturing with at least 10 employees, although a plant, once it is included, is generally still surveyed even if its employment level falls below the 10 employee cut-off point. The survey was started in 2000 and the response rate is estimated by Forfás to be around 55 to 60 percent of the targeted population per year. This data set provides information on services purchases, distinguishing imported and domestically procured services, as well as total R\&D expenditure at the plant level. Further data available from this source that is relevant to the current paper are total sales (as a measure of output), employment, expenditure on wages and total purchases, exports (distinguishing exports to the UK, EU and the rest of the world), expenditure on in-house training, nationality of ownership, and three digit sector of production. ${ }^{11,12}$

\footnotetext{
${ }^{11}$ Forfás defines foreign plants as plants that are majority-owned by foreign shareholders, i.e., where there is at least 50 per cent foreign ownership. While, arguably, plants with lower foreign ownership should still possibly considered to be foreign owned, this is not necessarily a problem for the case of Ireland since most inward foreign direct investment has been greenfield rather than acquisitions of local firms. Note that our
} 
In 2002, the survey also started collecting information on whether a plant uses the internet for their purchases of intermediates, and if so, how much as a percentage of sales. As we use this variable as an instrument for outsourcing in our econometric estimation, this necessarily restricts the time period of our econometric analysis to 2002 to 2004 . Fortunately, this is the most up-to-date data available from the survey which covers recent activity in international outsourcing of services.

In order to have a first look at the data and the possible relationship between $R \& D$ and outsourcing of services, Table 1 shows the means, medians and standard deviations for these variables from our plant level data, based on the sample that is also used in the regression analysis below.

The average ratio of internationally outsourced services to sales is around 4 percent over the period 2002 to 2004. There has been some increase in the arithmetic mean of this variable between 2003 and 2004 but it is difficult to judge whether this is persistent as no post-2004 years are available. We are also able to observe the extent of domestic outsourcing of services in our data. This is defined as the value of domestically procured services inputs relative to sales. The mean of this variable, shown in Table 1, represents around 20 to 22 percent in the period analysed. In the econometric analysis below, one important question is whether the effect of international and domestic outsourcing of services on innovation is similar or not.

As concerns the average R\&D intensity, the table indicates that the mean has fluctuated around 8 to 10 percent of sales, although the medians are far lower at around 0.3 percent. It is important to consider in this context that Ireland generally registers a relatively low level of R\&D intensity, a fact noted by the OECD (1998). Total business expenditure on R\&D in total amounted to only 0.8 percent of GDP which leaves Ireland

data only provide a dummy based on this definition rather than a percentage of ownership, and that this dummy relates to nationality of the plant in 2004, i.e., is fixed over time.

${ }^{12}$ All nominal variables are deflated using the consumer price index. 
closer to Mediterranean countries which in general are characterised by low-technology output than the Northern European countries which tend to have higher technological intensities and higher R\&D expenditures.

\section{[Table 1 here]}

Since we are investigating the relationship between international services outsourcing and the intensity of $\mathrm{R} \& \mathrm{D}$, it is illuminating to format the same information across the group of firms who do not procure any internationally outsourced services at all and those who do. We see from Table 2 that firms reporting at least some internationally outsourced services have, on average, higher R\&D intensities. They are also larger in terms of employee numbers and export more, on average, than their counterparts who do not report any internationally outsourced services. There is no obvious difference, however, in terms of profitability and investment in skills in the raw data. Of course, this simple look at the data does not allow controlling for the potential impact of any other variable, and this is something we will turn to in the next section.

\section{[Table 2 here]}

Before moving on to the results from our regressions, however, it is worthwhile looking briefly at which sectors are most actively engaged in international outsourcing of services. To do so, Table 3 reports the percentage of plants in each broad sector, which outsource at least some services internationally. The first impression we get is that there is considerable sectoral variation in international outsourcing. Within the services sector, Transport and Storage, Real estate \& Business services, and Community \& Personal services register the highest levels of internationally outsourced services. However, according to Forfás, the coverage of our data is not as exhaustive for services sectors as it is for manufacturing and, hence, is somewhat biased towards the latter. Within the set of manufacturing plants, at 67 percent, the Textiles sector has the highest proportion of firms 
purchasing service inputs on foreign markets. However Chemicals, Machinery and Transport Equipment are also in close range with percentages well close to 60 percent.

\section{[Table 3 here]}

\section{Econometric results}

In order to investigate the relationship between international outsourcing of services and R\&D activity more formally, we now turn to the estimation of equations (1) and (2). The results for various specifications of equation (1) are reported in Table 4. Column (1) reports the simplest specification of the model, only including international outsourcing, which is estimated using OLS to establish a benchmark. In this estimation we find that there is a positive and statistically significant association between international services outsourcing and R\&D activity, in line with expectations. This estimation does of course not control for unobserved plant level heterogeneity. In order to do so we estimate equation (1) using a (within transformation) fixed effects estimator in column (2). Hence, the coefficients are identified using the within-plant variation (deviations from the mean) in variables. $^{13}$ This does not change the positive coefficient on the outsourcing variable, though the coefficient size is now somewhat reduced from 0.30 to 0.17 .

The theoretical idea behind the empirical analysis is that outsourcing affects profits, which in turn enhances a firm's ability to invest in R\&D. In order to investigate whether our data is fully in line with this explanation we include an empirical measure of plant profitability in the model. As column (3) shows, the coefficient on this variable is positive and statistically significant as expected. However, it does not reduce the impact of the outsourcing variable, which is still positive and statistically significant. ${ }^{14}$ As pointed out in

\footnotetext{
${ }^{13}$ Specifically, this implies for the coefficient on international services outsourcing that it reflects the effect of within plant changes in outsourcing on changes in R\&D activity, as suggested by the theoretical model.

${ }^{14}$ Inspection shows that the coefficient is now larger than in column (2). This may be due to a strongly negative correlation in the raw data between international outsourcing and profitability. This negative
} 
Section 3, there are various explanations for why our empirical estimation may not fully capture the true impact of profits in this model: first, due to measurement problems, second, because including outsourcing and profits measured in the same period does not allow for a more long- or medium term impact of outsourcing on profits. Furthermore, outsourcing may indeed have a direct effect on innovation that is not mediated through profits, if it leads directly to restructuring in the firm towards more R\&D. This would only as a result affect profitability and, hence, would not be captured by the profits variable (which is measured in the same period as outsourcing) in the empirical estimation.

The model thus far may be mis-specified as it does not consider domestic outsourcing. From an empirical point of view, if domestic and international outsourcing decisions are correlated then not controlling for the former in the estimation would lead to a biased coefficient on the latter. Furthermore, firms may also outsource materials and, if these decisions are correlated with services sourcing and are not controlled for this may lead to biased coefficients. Column (4), therefore, presents estimation results which include a measure of domestic outsourcing of services, as well as outsourcing of materials. Domestic services sourcing returns a statistically significantly positive coefficient, as does domestic sourcing of materials. It can also be noted that the coefficient size on the international outsourcing variable is now reduced, suggesting that in the model in column (3) the effect of domestic and international outsourcing of services and materials are confounded. While it appears from a casual look that the coefficient on international outsourcing of services is higher than that of domestic services sourcing (which may be expected, as it provides more opportunities for exploiting international factor cost differences), a simple F-test does not allow us to reject the hypothesis that the two are statistically equal (probability value 0.19). However, as we show below, once endogeneity 
of the outsourcing variables is taken adequately into account, the effects of the two types of outsourcing become statistically different.

The assumption in the analysis thus far that international and domestic services outsourcing are treated as exogenous is arguably problematic. ${ }^{15}$ While the lagged variable is intended to address this problem this may not be sufficient. In order to deal with this more appropriately we therefore now proceed to treat international and domestic outsourcing of services and materials explicitly as endogenous in the estimation. The challenge is to find instrumental variables candidates that are highly correlated with outsourcing but not with the error term in equation (1).

We use the following instruments for outsourcing: first, twice lagged growth rates of international and domestic outsourcing of services and materials intensities, as these are expected to be highly correlated with lagged levels of outsourcing, but a priori are not obviously correlated with the error term. Second, we use a dummy indicating whether a plant exports to the UK, as well as the share of exports relative to sales by a plant that are directed to the UK rather than other export markets. The choice of these variables is inspired by Ruane and Sutherland (2005) who find that there is little evidence that Irish firms that export to the UK have performance premia compared to non-exporters. However, they find that Irish exporters compared to the rest of the world are clearly more productive, technology intensive and pay higher wages. Hence, while exporting to the UK clearly indicates cross border engagement, which may also help to find partners for international outsourcing, this variable should be less correlated with R\&D activity. Furthermore, we use the percentage of inputs purchased over the web as an additional instrument. Again, this should be correlated with services outsourcing but is likely to be

\footnotetext{
${ }^{15}$ For example, Bartel et al. (2005) argue that technological change is partly responsible for the increase in outsourcing and if general technological change is correlated with plant level R\&D expenditure then this may cause an endogeneity problem.
} 
orthogonal to R\&D. As a matter of course, we test for the validity and relevance of the instruments in the estimations.

Column (5) presents the estimation result. Note that the instruments used for services and materials outsourcing are valid as indicated by the Sargan test for overidentifying restrictions, which cannot reject the hypothesis of instrument validity. Furthermore, we ascertain that the instruments used are relevant in that they exhibit sufficiently strong correlation with the instrumented variable. We report the F-statistic for the excluded instruments (and associated p-value) from the first-stage regression. ${ }^{16}$ When the F-statistic is small (or the corresponding p-value is large), the instrumental variable estimates and confidence intervals would be unreliable. We find that our instruments are appropriate on this criterion.

The regression results confirm the importance of international outsourcing of services for R\&D activity. Taking the point estimate at face value suggests that an increase in the ratio of internationally outsourced services to sales by one percentage point increases the $R \& D$ ratio by 2.5 percentage points. This is an economically important effect. The IV regression also shows that the coefficient on international services outsourcing is higher than that on domestic outsourcing, the magnitude of which remains unchanged. This difference is confirmed in an F-test, which rejects the equality of the two coefficients (pvalue 0.00$)$.

To sum up, our analysis thus far suggests an important role for international services outsourcing for plants' innovative activity. This effect is not fully captured by profits in the same period. Also, international outsourcing is more important than the impact of domestic outsourcing of services. ${ }^{17}$

\footnotetext{
${ }^{16}$ The F-statistic tests the hypothesis that the instruments should be excluded from the first-stage regressions.

${ }^{17}$ In terms of the control variables we find in column (5) that employment is negatively correlated, a result in line with, e.g., Acs and Audretsch (1991) who argue that small firms may not be able to bear the costs of the
} 


\section{[Table 4 here]}

Theory posits that international services outsourcing allows firms to increase profits, as they have access to cheaper intermediate inputs abroad. As shown above, this mechanism is not fully captured in our data, as inclusion of the profit variable does not negate the impact of the outsourcing measure in the R\&D equation. Still, it is of interest as to whether there is any positive relationship between international services outsourcing and profits, and we now turn to investigate this link with our data by estimating different specifications of equation (2). The results are reported in Table 5. Column (1) presents a specification which is based on a (within transformation) fixed effects estimator and only includes the two services outsourcing variables. Column (2) shows coefficients obtained from a fixed effects estimation including materials outsourcing and sectoral variables. Column (3) shows an equivalent IV regression on within transformed variables, and column (3) also presents a similar IV regression but including more plant level controls. ${ }^{18}$

All estimations show that international services outsourcing has a positive effect on profitability, as expected. The point estimate in column (3) indicates that a one percentage point increase in the international services outsourcing intensity increases the profit ratio by roughly 0.4 percentage points. However, we also find a consistently negative effect on profits from domestic outsourcing of services. This even holds in the IV estimations which treat the variable as endogenous using suitable and valid instruments.

\section{[Table 5 here]}

The analysis thus far treats equations (1) and (2) as unrelated and, hence, they are estimated separately. However, it is arguable that the profit variable is endogenous in equation (1) and, furthermore, that the error terms in both equations may be correlated as

high expenditure on setting up and running R\&D facilities. The coefficients on the export and training dummy variables are not statistically significant.

${ }^{18}$ International and domestic outsourcing intensities are treated as endogeneous, using the same instruments as in the estimation of equation (1). The tests again support the validity and relevance of the chosen instruments. 
the dependent variable in (2), as well as other covariates, are also included as exogenous variables in equation (1). If this is the case then estimating the two equations jointly improves efficiency of the estimates. Hence, we now proceed to treat (1) and (2) as a system of equations and estimate them jointly using 3 stage least squares (3SLS) techniques. We also treat services outsourcing as endogenous using the same set of instruments as employed previously. The results are reported in Table 6.

In the R\&D equation in column (1) we see that the signs, significance and magnitude of the coefficients is very similar to those reported in the IV regression in Table (4). In the profit equation we still find a negative and statistically significant coefficient on domestic outsourcing, although the coefficients size is somewhat smaller than in the IV regressions in Table 5. The coefficient on international services outsourcing is still positive and statistically significant, but has doubled in size: the point estimate now suggests that a one percentage point increase in international services outsourcing increases profitability by almost 0.9 percentage points.

\section{[Table 6 here]}

\section{Conclusions}

Recent breakthroughs in information technology and the wholesale adoption of purchasing media such as the internet have provided scope for an explosion in the proportions of services that are outsourced internationally. Theory has something to say about the predicted effect of internationally outsourced inputs on the ability of a firm to sustain growth through its growth in innovative activity. Starting from these theoretical predictions we provide, to the best of our knowledge for the first time, a comprehensive empirical analysis of the link between international outsourcing, domestic sourcing, profits and innovation using plant level data covering the recent period 2002 to 2004. 
Consistent with the predictions of theory (e.g., Glass and Saggi, 2001) we observe a positive relationship between international outsourcing of services and innovative activity, measured in terms of $R \& D$, at the plant level. Such a positive effect can also be observed for domestic outsourcing of services, but the magnitude is smaller. This makes intuitive sense, as international outsourcing allows more scope for exploiting international factor price differentials, therefore giving the establishment higher profits and more scope to restructure production activities towards innovation. We also find, again in line with theory, that international outsourcing has a positive effect on profitability, although this does not appear to be the case for domestic outsourcing. ${ }^{19}$ Overall, the outsourcing of international services is seen in our analysis as a force for the good: a firm's innovation rates rise, hence allowing plants to continue to shift their technological frontier further outwards and, hence, sustaining their competitive position.

A recent fear even among proponents of international outsourcing is that developed countries started with outsourcing unskilled-intensive (manufacturing) production but have now moved to skilled-intensive (including services) activities also. If this process continues it may lead to a "hollowing out" of production in the industrialised countries. ${ }^{20}$ However, if international services outsourcing indeed promotes innovation, as our analysis suggests, then there is a case to be made for its continuance. If involvement in international outsourcing causes the technology frontier to shift through further innovation, the technological gap between industrialised and industrialising countries remains and outsourcing is then a persistent strategy. Thus understanding the impact of international outsourcing on innovation is key to understanding whether we can expect it to continue in the future.

\footnotetext{
${ }^{19}$ This result can be explained by recent models such as Leahy and Montagna (2008) which show that outsourcing can lead reductions in profits.

${ }^{20}$ See Sinn (2006) for an argument along those lines made for the particular example of Germany.
} 


\section{References}

Acs, Z. and D. Audretsch (1991), "Innovation and the size at the firm level”, Southern Economic Journal, 57, 739-744.

Amiti, M. and S.J. Wei (2006), "Service outsourcing, productivity and employment: Evidence from the US”, CEPR Discussion Paper 5475.

Antrás, P. and E. Helpman (2004), “Global Sourcing”, Journal of Political Economy, 112: 552-580.

Bartel, A., S. Lach and N. Sicherman, 2005, "Outsourcing and technological change”, NBER Working Paper 11158

Blinder, Alan S., 2006, “Offshoring: The next industrial revolution?”, Foreign Affairs, 85(2).

Cassidy, M., H. Görg and E. Strobl, 2005, Knowledge accumulation and productivity: Evidence from plant level data for Ireland, Scottish Journal of Political Economy, 52, 344358

Criscuolo, C., J.E. Haskel and M.J. Slaughter, 2005, Global engagement and the innovation activities of firms, NBER Working Paper 11479.

Davidson, C. and S. Matusz, 2000, "Globalization and labor market adjustment: How fast and at what cost?", Oxford Review of Economic Policy, 16(3), 42-56

Deutsche Bank, 2004, “Offshoring: Globalisation Wave reaches the service sector", Deutsche Bank Research

Eaton, J. and S. Kortum, 2006, 'Innovation, Diffusion, and Trade', NBER Working Paper 12385

Feenstra, R.C. and G.H. Hanson (1999), "The Impact of Outsourcing and High-Technology Capital on Wages: Estimates for the United States, 1979-1990”, Quarterly Journal of Economics, 114, 907-941.

Geishecker, I. and H. Görg (2008), "Winners and losers: A micro-level analysis of international outsourcing and wages", Canadian Journal of Economics, 41, 243-270

Glass, A. and K. Saggi, 2001, "Innovation and wage effects of international outsourcing”, European Economic Review, 45, 67-86

Görg, H. (2000). Fragmentation and trade: US inward processing trade in the EU. Review of World Economics, 136, 403-422

Görg, H., A. Hanley and E. Strobl (2008), "Productivity effects of international outsourcing: Evidence from plant level data”, Canadian Journal of Economics, 41, 670688. 
Head, Keith, and John Ries (2002) 'Offshore Production and Skill Upgrading by Japanese Manufacturing Firms,’ Journal of International Economics 58, 81-105

Hijzen, A., T. Inui and Y. Todo (2009), Does offshoring pay? Firm level evidence from Japan, Economic Inquiry, forthcoming.

Kohn, M. and J.T. Scott (1982), Scale economies in research and development: The Schumpeterian hypothesis, Journal of Industrial Economics, 30, 239-249.

Leahy, D. and C. Montagna (2008), Make or buy in international oligopoly and the role of competitive pressure, GEP Research Paper, University of Nottingham

OECD, 1998, Internationalisation of Industrial R\&D: Patterns and Trends. Paris: OECD

Redding, S. (1996). "The Low-skill, Low-quality Trap: Strategic Complementarities between Human Capital and R \& D", Economic Journal, 106, 458-470

Ruane, F. and J. Sutherland, 2005, 'Export Performance and Destination Characteristics of Irish Manufacturing Industry’, Review of World Economics, 141, 442-59

Salomon, R.M. and J.M. Shaver (2005) "Learning by exporting: New insights from examining firm innovation”, Journal of Economics and Management Strategy, 14, 431-460.

Shepherd, W.G. (1972), "The elements of market structure”, Review of Economics and Statistics, 54, 25-37

Sinn, H.W., 2006, The Pathological Export Boom and the Bazaar Effect. How to Solve the German Puzzle, CESifo Working Paper No. 1708

Swenson, D. (2000). Firm outsourcing decisions: evidence from U.S. foreign trade zones. Economic Inquiry, 38, 175-189.

Swenson, D. (2004). Entry costs and outsourcing decisions: evidence from the U.S. overseas assembly provision. North American Journal of Economics and Finance, 15(3).

Tomiura, E. 2007, Foreign outsourcing, exporting, and FDI: a productivity comparison at the firm level, Journal of International Economics 72, 113-27

Tomiura, E. 2009, Foreign versus domestic outsourcing: Firm-level evidence on the role of technology, International Review of Economics and Finance 18, 219-226

Van Dijk, B., R. den Hertog, B. Menkveld and R. Thurik (1997), „Some new evidence o the determinants of large- and small-firm innovation“, Small Business Economics, 9, 335343. 
Table 1: Summary statistics: $R \& D$ and outsourcing

\begin{tabular}{|l|l|l|l|l|}
\hline & & 2002 & 2003 & 2004 \\
\hline $\begin{array}{l}\text { International } \\
\text { services outsourcing }\end{array}$ & mean & 0.042 & 0.036 & 0.047 \\
\hline & median & 0.008 & 0.008 & 0.008 \\
\hline & std.dev. & 0.325 & 0.108 & 0.325 \\
\hline & obs. & 1596 & 1596 & 1701 \\
\hline & & & & \\
\hline R\&D intensity & mean & 0.080 & 0.105 & 0.097 \\
\hline & median & 0.003 & 0.004 & 0.003 \\
\hline & std.dev. & 0.771 & 0.961 & 0.826 \\
\hline & obs. & 1596 & 1596 & 1701 \\
\hline & & & & 0.226 \\
\hline $\begin{array}{l}\text { Domestic services } \\
\text { outsourcing }\end{array}$ & mean & 0.201 & 0.206 & 0.121 \\
\hline & median & 0.119 & 0.120 & 1.067 \\
\hline & std.dev. & 0.794 & 0.802 & 1701 \\
\hline & obs. & 1596 & 1596 & \\
\hline
\end{tabular}

Variable definitions:

R\&D intensity: expenditure on R\&D / sales

International services outsourcing: imported services inputs / sales

Domestic services outsourcing: domestic services inputs / sales

Table 2: Summary statistics by outsourcing activity

\begin{tabular}{|c|c|c|c|c|c|c|}
\hline & & $\begin{array}{l}\text { R\&D } \\
\text { intensity }\end{array}$ & Profit ratio & employment & $\begin{array}{l}\text { training } \\
\text { intensity }\end{array}$ & $\begin{array}{l}\text { export } \\
\text { intensity }\end{array}$ \\
\hline \multirow{3}{*}{$\begin{array}{lr}\text { No international } \\
\text { services outsourcing }\end{array}$} & median & 0.001 & 0.058 & 31 & 0.002 & 0.200 \\
\hline & std.dev. & 0.948 & 6.742 & 228 & 0.034 & 0.396 \\
\hline & obs. & 1517 & & & & \\
\hline \multirow{3}{*}{$\begin{array}{l}\text { International } \\
\text { services outsourcing }\end{array}$} & median & 0.006 & 0.055 & 44 & 0.002 & 0.72 \\
\hline & std.dev. & 0.845 & 5.481 & 312 & 0.056 & 0.390 \\
\hline & obs. & 1780 & & & & \\
\hline & & & & & & \\
\hline
\end{tabular}

\section{Variable definitions:}

R\&D intensity: expenditure on R\&D / sales

Profit ratio: (sales - wages - total purchases) / sales)

employment: number of employees

training intensity: expenditure on in-house training / sales

export intensity: exports / sales 
Table 3: Percentage of plants in sector outsourcing at least some services

\begin{tabular}{|c|c|c|c|}
\hline STAN code & Description & Number of plants & \% of total sector \\
\hline 1 & Food, beverages and tobacco & 216 & 49.8 \\
\hline 2 & Textiles, leather and footwear & 80 & 66.7 \\
\hline 3 & Wood and wood products & 53 & 52.5 \\
\hline 4 & Pulp, paper, printing \& publishing & 52 & 38.5 \\
\hline 5 & Chemicals, rubber \& plastics & 221 & 52.1 \\
\hline 6 & non-metallic mineral products & 45 & 39.1 \\
\hline 7 & Basic and fabricated metal products & 106 & 58.5 \\
\hline 8 & Machinery and equipment & 393 & 58.8 \\
\hline 9 & Transport equipment & 40 & 50.5 \\
\hline 10 & Other manufacturing and recycling & 91 & 45.2 \\
\hline 11 & Wholesale and retail trade & 19 & 40.0 \\
\hline 12 & Hotels and restaurants & 2 & 57.9 \\
\hline 13 & Transport and storage & 11 & 53.9 \\
\hline 14 & Post and telecommunications & 7 & 42.9 \\
\hline 15 & Financial intermediation & 376 & 56.9 \\
\hline 16 & Real estate, renting \& business services & 50 & 63.3 \\
\hline 17 & Community, social \& personal services & 1774 & 54.2 \\
\hline
\end{tabular}


Table 4: $R \& D$ equation

\begin{tabular}{|c|c|c|c|c|c|}
\hline & (1) & (2) & (3) & (4) & (5) \\
\hline & OLS & FE & FE & $\mathrm{FE}$ & IV \\
\hline \multirow{2}{*}{$\begin{array}{l}\text { International services } \\
\text { outsourcing }\end{array}$} & 0.302 & 0.164 & 0.873 & 0.389 & 2.481 \\
\hline & $(0.158)^{*}$ & $(0.075)^{* *}$ & $(0.111)^{* * *}$ & $(0.153)^{* *}$ & $(0.136)^{* * *}$ \\
\hline \multirow[t]{2}{*}{$\begin{array}{l}\text { Domestic services } \\
\text { outsourcing }\end{array}$} & & & & 0.178 & 0.176 \\
\hline & & & & $(0.040)^{* * *}$ & $(0.020) * * *$ \\
\hline \multirow[t]{2}{*}{$\begin{array}{l}\text { International material } \\
\text { outsourcing }\end{array}$} & & & & -0.003 & 0.110 \\
\hline & & & & $(0.360)$ & $(0.054)^{* *}$ \\
\hline \multirow[t]{2}{*}{$\begin{array}{l}\text { Domestic material } \\
\text { outsourcing }\end{array}$} & & & & 0.913 & 0.165 \\
\hline & & & & $(0.330)^{* * *}$ & $(0.103)$ \\
\hline \multirow[t]{2}{*}{ Profit ratio } & & & 0.100 & 0.122 & 0.300 \\
\hline & & & $(0.012) * * *$ & $(0.013)^{* * *}$ & $(0.011)^{* * *}$ \\
\hline \multirow[t]{2}{*}{ Training } & 0.031 & 0.335 & 0.304 & 0.274 & 0.036 \\
\hline & $(0.062)$ & $(0.116)^{* * *}$ & $(0.113)^{* * *}$ & $(0.112)^{* *}$ & $(0.099)$ \\
\hline \multirow[t]{2}{*}{ Export dummy } & -0.209 & 0.065 & 0.137 & 0.114 & -0.268 \\
\hline & $(0.115)^{*}$ & $(0.170)$ & $(0.165)$ & $(0.164)$ & $(0.128)^{* *}$ \\
\hline \multirow[t]{2}{*}{ Employment } & -0.048 & -0.047 & -0.002 & 0.034 & -0.094 \\
\hline & $(0.010)^{* * *}$ & $(0.119)$ & $(0.116)$ & $(0.115)$ & $(0.106)$ \\
\hline Observations & 3297 & 3297 & 3297 & 3297 & 3297 \\
\hline Plants & 1929 & 1929 & 1929 & 1929 & 1929 \\
\hline $\begin{array}{l}\text { F-test international } \\
\text { service outsourcing }\end{array}$ & & & & & 1469.31 \\
\hline $\begin{array}{l}\text { F-test domestic service } \\
\text { outsourcing }\end{array}$ & & & & & 423.87 \\
\hline $\begin{array}{l}\text { F-test international } \\
\text { material outsourcing }\end{array}$ & & & & & 455.26 \\
\hline $\begin{array}{l}\text { F-test domestic } \\
\text { material outsourcing }\end{array}$ & & & & & 451.64 \\
\hline Sargan test (p-value) & & & & & 0.23 \\
\hline R-squared & 0.06 & 0.01 & 0.06 & 0.08 & 0.23 \\
\hline
\end{tabular}

Dependent variable: $R \& D$ intensity as defined in notes to table 1

Column (5) is an IV regression on within transformed variables.

Instrumented variables are international and domestic outsourcing of services and materials.

Instruments used are twice lagged growth of outsourcing variables, dummy for exporting to the UK, export

intensity to UK, dummy for purchases of inputs via the web

Regression includes constant and full sets of three digit industry and time dummies

All RHS variables are lagged one period

standard errors in parentheses

* significant at $10 \%$; ** significant at $5 \%$; *** significant at $1 \%$ 
Table 5: Profit equation

\begin{tabular}{|c|c|c|c|c|}
\hline & (1) & (2) & (3) & (4) \\
\hline & $\mathrm{FE}$ & $\mathrm{FE}$ & IV & IV \\
\hline \multirow[t]{2}{*}{ International services outsourcing } & 0.491 & 0.516 & 0.413 & 0.413 \\
\hline & $(0.417)$ & $(0.419)^{*}$ & $(0.215)^{*}$ & $(0.215)^{*}$ \\
\hline \multirow[t]{2}{*}{ Domestic services outsourcing } & -0.299 & -0.305 & -0.441 & -0.440 \\
\hline & $(0.100)^{* * *}$ & $(0.101)^{* * *}$ & $(0.035)^{* * *}$ & $(0.036)^{* * *}$ \\
\hline \multirow[t]{2}{*}{ International material sourcing } & & 1.386 & 0.035 & 0.034 \\
\hline & & $(0.691)^{* *}$ & $(0.096)$ & $(0.096)$ \\
\hline \multirow[t]{2}{*}{ Domestic material sourcing } & & 0.138 & 0.396 & 0.399 \\
\hline & & $(0.210)$ & $(0.182)^{* *}$ & $(0.183)^{* *}$ \\
\hline \multirow[t]{2}{*}{ Industry sales } & & 0.288 & 0.087 & 0.090 \\
\hline & & $(0.448)$ & $(0.253)$ & $(0.254)$ \\
\hline \multirow[t]{2}{*}{ Market share } & & -0.000 & -0.000 & -0.000 \\
\hline & & $(0.000)$ & $(0.000)$ & $(0.000)$ \\
\hline \multirow[t]{2}{*}{ Training dummy } & & & & -0.074 \\
\hline & & & & $(0.177)$ \\
\hline \multirow[t]{2}{*}{ Export dummy } & & & & 0.053 \\
\hline & & & & $(0.229)$ \\
\hline \multirow[t]{2}{*}{ Employment } & & & & -0.011 \\
\hline & & & & $(0.190)$ \\
\hline Observations & 3297 & 3297 & 3297 & 3297 \\
\hline Plants & 1929 & 1929 & 1929 & 1929 \\
\hline $\begin{array}{l}\text { F-test international service } \\
\text { outsourcing }\end{array}$ & & & 2128.52 & 2114.67 \\
\hline $\begin{array}{l}\text { F-test domestic service } \\
\text { outsourcing }\end{array}$ & & & 488.67 & 474.90 \\
\hline $\begin{array}{l}\text { F-test international material } \\
\text { outsourcing }\end{array}$ & & & 455.68 & 455.27 \\
\hline $\begin{array}{l}\text { F-test domestic material } \\
\text { outsourcing }\end{array}$ & & & 458.02 & 454.56 \\
\hline Sargan test (p-value) & & & 0.15 & 0.14 \\
\hline R-squared & 0.04 & 0.02 & 0.03 & 0.03 \\
\hline
\end{tabular}

Dependent variable: profit ratio as defined in notes to table 2

Columns (3) and (4) are IV regressions on within transformed variables.

Instrumented variables are international and domestic outsourcing of services and materials.

Instruments used are twice lagged growth of outsourcing variables, dummy for exporting to the UK, export

intensity to UK, dummy for purchases of inputs via the web

Regression includes constant and full sets of three digit industry and time dummies

All RHS variables are lagged one period

Standard errors in parentheses

* significant at $10 \%$; ** significant at $5 \%$; *** significant at $1 \%$ 
Table 6: Simultaneous estimation

\begin{tabular}{|l|l|l|}
\hline & $(1)$ & $(2)$ \\
\hline International services outsourcing & R\&D intensity & Profit ratio \\
\hline & 2.506 & 0.897 \\
\hline Domestic services outsourcing & $(0.116)^{* * *}$ & $(0.193)^{* * *}$ \\
\hline & 0.145 & -0.311 \\
\hline International material outsourcing & $(0.014)^{* * *}$ & $(0.025)^{* * *}$ \\
\hline & 0.135 & 0.035 \\
\hline Domestic material outsourcing & $(0.038)^{* * *}$ & $(0.068)$ \\
\hline & 0.103 & 0.074 \\
\hline Profit ratio & $(0.072)$ & $(0.128)$ \\
\hline & 0.259 & \\
\hline Training & $(0.008)^{* * *}$ & \\
\hline & 0.053 & -0.072 \\
\hline Export dummy & $(0.098)$ & $(0.175)$ \\
\hline & -0.286 & 0.159 \\
\hline Employment & $(0.126)^{* *}$ & $(0.225)$ \\
\hline & -0.065 & -0.175 \\
\hline Industry sales & $(0.104)$ & $(0.186)$ \\
\hline & & 0.170 \\
\hline Market share & & $(0.199)$ \\
\hline & & 0.000 \\
\hline Observations & & $(0.000)$ \\
\hline R-squared & 3297 & 3297 \\
\hline & 0.24 & 0.05 \\
\hline & & \\
\hline & & \\
\hline & & \\
\hline & & \\
\hline & & \\
\hline & & \\
\hline & & \\
\hline & & \\
\hline & & \\
\hline & & \\
\hline
\end{tabular}

3SLS regression on within transformed variables.

International and domestic outsourcing variables assumed endogenous, instruments as before. Standard errors in parentheses

* significant at $10 \%$; ** significant at $5 \%$; *** significant at $1 \%$ 